\title{
IMPLEMENTATION OF INVESTMENT FUNDS SHARING AGREEMENT IN SHARIA BANKING SYSTEM IN INDONESIA
}

\author{
Evita Isretno Israhadi \\ Faculty of Law, Borobudur University \\ evita_isretno@borobudur.ac.id
}

\begin{abstract}
Mudharabah financing investment, also known as trust financing, is a method of distributing funds in Sharia banking to comply with the religious prohibition of interest on loans. However, the use of legal protection has not been maximized in increasing the growth of mudharabah financing investment products, especially for SMEs (Micro, Small and Medium Enterprises), due to the complicated process of filing and guarantees needed by the bank. This study, therefore aims to implement adequate investment funds sharing agreement in Indonesia's Sharia Banking System for mudharabah investments to be felt in all categories. The result showed that regulatory restructuring is needed for the application of mudharabah investment to be a real sector driver without eliminating the purity of Islamic principles.
\end{abstract}

Keywords: Mudharabah; Micro, Small, and Medium Enterprises; Sharia Banking System

\section{Introduction}

The establishment of Syariah Muamalat Indonesia Bank Inc. in 1991 with the commencement of operational activities in 1992 was the starting point for the interest-free banking industry in Indonesia. The establishment of the bank was initiated by the Indonesian Ulema Council (MUI), the government, and supported by the Indonesian Muslim Intellectuals Association (ICMI) as well as several Muslim entrepreneurs. Support from the community was evidenced by their commitment to purchase shares from the Company amounting to $\mathrm{Rp}$. $84,000,000,000$, with an additional fund of Rp. 106,000,000,000 from the people of West Java. ${ }^{1}$

Government Regulation Number 72 of 1992 concerning Banks is an opportunity for individuals and organizations to run a business based on profit sharing. In addition, Law Number 7 of 1992 is an advanced stage for the legitimacy process of introducing a profit-sharing system, while Law Number 10 of 1998 is a form of a business carried out for Muslims seeking for noninterest intermediation institutions.

The implementation of this law legalizes the banking dualism system in Indonesia and becomes the driver for its development based on sharia principles. This is reflected in Article 1 number 3, which defined a commercial bank as a bank that carries on conventional business

1 Zainuddin Ali, Hukum Perbankan Syariah, 2nd ed. (Jakarta: Sinar Grafindo, 2010). 
activities based on sharia principles, which is then followed up with Law Number 23 of 1999 concerning Bank of Indonesia.

The growth and development of Sharia Banks and Business Units and ratification of Law Number 21 the Year 2008 on Sharia Banking leads to the existence of interest-free intermediary financial institutions. The existence of this law tends to meet the needs of the Muslim communities in carrying out business activities through intermediary institutions that are free from the practice of maisir, gharar, haram, and usury. ${ }^{2}$

The crystallization of religious values contained in the law influences the application of prohibited business activities in the form of sharia products. This is dissimilar to the conventional banking system, which performs its intermediary financial function using the principle of interest, which, according to the sharia view, is equivalent to usury. Law Number 21 of 2008 encourages the establishment of Sharia banks, which contribute to the development of people's economy as mandated in the 1945 Constitution. In addition, other activities in line with this are stated in article 33 paragraphs (4).

The most appropriate economic institutions to translate sharia banking are based on the following considerations: 1) the aspirations of the Indonesia community that are majorlyMicro, Small and Medium Enterprises (MSMEs) business owners and the principles of economic democracy; 2) prioritizing the principle of togetherness; 3) the principles of justice and independence; 4) It is not permissible to support or partner with entrepreneurs or companies involved in environmental damages (the sustainable and environmental principles); 5) Combining worldly demands with hereafter / uhrawi (the principle of balance); and 6) prioritizing the progress of the real sector, which is based on natural and human resources (the principle of national unity). ${ }^{3}$

Micro, Small and Medium Enterprises (MSMEs) tend to use a large amount of the sharia banking services in the form of murabaha (cost-plus financing) compared to Mudharabah (trust financing) and musyarakah (partnership). This is because Mudharabah services cannot be accessed maximally because the conditions imposed by the Sharia Bank are incapable and

2 Abdul Rahim Abdul Rahman, "Islamic Microfinance: A Missing Component in Islamic Banking” 2 (2007): 3853.

3 Zubairi Hasan, Undang-Undang Perbankan Syariah, Titik Temu Hukum Islam Dan Hukum Nasional, (Jakarta: Rajawali Pers, 2009). 
difficult to fulfill by the SMEs. However, easy benefits are felt by medium enterprise entrepreneurs and groups such as cooperatives due to the use of adequate integrity as collateral. ${ }^{4}$

There are several financing products in Sharia banking, such as investment financing, also known as mudharabah which uses the principle of profit sharing between banks and customers. Mudharabah financing in sharia banking is free from maisir, gharar, haram, and usury (magrib). ${ }^{5}$ Its products are capital providers (shahibul mal) and managers (mudarib), with the application of banking principles applied in the form of a product contract.

Based on the presentation and development of the law associated with the Islamic banking system, it is, therefore, interesting to study the application of sharia principles related to legal issues, by answering the following questions: 1) why hasn't mudharabah financing as a driver in the real sector through empowerment MSME been properly implemented?; 2) Is the application of mudharabah contract and legal acceleration a financing investment?

The theory of Agreement, which consists of worldly and ukhrawi (hereafter) consequences based on Islamic law is used to explain the problem associated with Sharia banks. The products produced by banks, are inseparable from the transaction process, which in term of fiqh muamalah is called an Akad. ${ }^{6}$ In addition, the agreement is carried out is binding (mulzim), where all parties need to possess good faith (husnan-niyah), pay attention to the provisions or economic traditions applied in society as long as they do not conflict with the principle of the agreement (al-uqud) and all parties have the freedom to determine the terms of the agreement as long as they do not violate Islamic morals. ${ }^{7}$

Based on Islamic law, there are two terms used in the Quran, 'ahdu and 'aqdu. The word 'ahdu means a one-sided agreement made by someone without consulting the other party, while the word' $a q d u$ is an equivalent agreement (verbintenis) where each party has mutual relationship. ${ }^{8}$ Therefore, 'aqdu occurs between the two parties, since the agreement which originated from' $a h d u$ applies to both, with similarities when related to the civil law system. The civil law recognizes agreements and commitments, while the Quran consists of three terms, 'ahdu (agreement), interlocking' $a h d u$ one with another (agreement), and 'aqdu (engagement).

\footnotetext{
4 Bertha Kusuma Wardani and Joko Pramono, "Perbankan Syariah: Alternatif Pendanaan Usaha Mikro, Kecil, Menengah (UMKM)" 9, no. 17 (2016): 60-78.

5 Zainuddin Ali, Hukum Perbankan Syariah, 2nd ed. (Sinar Grafindo, 2010).

6 Syafri Harahap, "The Disclosure of Islamic Values - Annual Report The Analysis of Bank Muamalat Indonesia ' s Annual Report” 29 (2003): 70-89, https://doi.org/10.1108/03074350310768355.

7 Gemala Dewi, Aspek-Aspek Hukum Perbankan Dan Perasuransian Syariah Di Indonesia (Jakarta: Kencana Prenada Media Group, 2006).

8 Abdoerraoef, Al-Quran Dan Ilmu Hukum (Jakarta: Bulan Bintang, 1970).
} 
Occurrence of consent granted (qabul) or agreement in science, consists of several middlerange theories as follows: 1) Theory of Will (wish theorie) with the agreement considered to occur assuming the parties stated their interest; 2) Theory of Trust (vetrouwenstheori), with an agreement considered to have occurred when the statement of one party is objectively trusted by the other; 3) Speech Theory (uitingstheori), an agreement is considered to have occurred when the debtor expresses approval of the offer made by the creditor; 4) Theory of Delivery (verzendingstheorie), an agreement is considered to have occurred when the debtor sends a response letter to the creditor; 5) Theory of Acceptance (ontvangstheorie), an agreement is considered to have occurred when the creditor knows that the debtor has accepted the offer. ${ }^{9}$

This study, therefore, utilized the theory of venture, which influences the implementation of mudharabah financing investments with profit-sharing principles. This theory is a contractual agreement in a financing investment that does not provide certainty of income (natural uncertainty contracts) in terms of quantity and time with returns that can be positive, negative, or even zero. ${ }^{10}$ Karim, defined this kind of investment agreement as "sunnatullah" (by their nature) and did not offer a fixed and definite return. ${ }^{11}$

This type of contract requires all parties to combine their real and financial assets into one unit and bear all risks associated with profits and losses together. Mudharabah financing belongs to the category of natural uncertainty contracts based on the theory of venture. ${ }^{12}$

The implementation of mudharabah financing agreements as movers in the real sector through empowering MSMEs is faced with various obstacles. ${ }^{13}$ It conflicts with the implementation of Sharia banking activities therefore, it has not been maximized in meeting expectations, in accordance with Law Number 21 of 2008. The implementation and the acceleration of legal law for mudharabah financing investments is beneficial as a means of developing family and social economy for MSMEs based on laws and regulations.

9 Supramono Gatot, Perikatan Dan Masalah (Jakarta: Djembatan, 1966).

10 AbdulRazzaq Abdul-Majeed Alaro and Abdulrahman Habeeb Alalubosa, "Potential of Shar īah Compliant Microfinance in Alleviating Poverty in Nigeria A Lesson from Bangladesh," International Journal of Islamic and Middle Esstern Finance and Management, 2018, https://doi.org/10.1108/IMEFM-01-2017-0021.

11 Adiwarman A Karim, Bank Islam-Analisis Fiqih Dan Keuangan, 3rd ed. (Jakarta: Raja Grafindo Persada, 2007).

12 Aishath Muneeza, Nik Nurul Atiqah Nik Yusuf, and Rusni Hassan, "The Possibility of Application of Salam in Malaysian Islamic Banking System,” 2011, https://doi.org/10.1108/08288661111135135.

13 Hanik Amalia, "Peran Pembiayaan Mudharabah Pada Baitul Maal Wat Tamwil (BMT) Dalam Melakukan Pengembangan Usaha Mikro Kecil Dan Menengah (UMKM),” 2019. 


\section{Methods}

The presence of Sharia Banking law is inseparable from the history of the development of positive law in Indonesia, which is influenced by Islamic, customary, and western laws. One of the norms of Islamic law in the field of muamalat is currently marked by the presence of banks that apply sharia principles in their operation, which is in accordance with Law Number 21 the Year 2008. The policies and development of sharia economics in banks are based on laws and regulations. This is an inseparable part that aims to improve the national banking system, which is oriented to strengthening national economic fundamentals. According to Fuadi, the emergence of banks based on sharia principles, adds to the liveliness of the law and also reinforces the vision of banking life in Indonesia. ${ }^{14}$

In carrying out Islamic principles, it is forbidden to conduct magrib (maisir, gharar and riba / usury) because Sharia banks do not impose the interest system in every business activity. In the Islamic economy, all activities need to be carried out following the law and good (halalan thayyiban) as well as from the perspective of Islamic values and morality, including the business carried out by Sharia banking. ${ }^{15}$ The opposite of halalan thayyiban is haram, which means a forbidden act leads to sin, which is to the detriment of others. According to the rule of law, all things are prohibited, unless there are provisions based on the Quran and as-Sunnah as the main source. In the interaction between humans in society (muamalah), everything is permitted unless an argument prohibits its existence.

The Decree of the Directors of Indonesia Bank Number 32/34 / Kep / Dir. May 12, 1999, concerning Commercial Banks and based on Sharia Principles, as well as the Number 32/36 / Kep / Dir. May 12, 1999, concerning Rural Credit, is a policy developed for business activities. In addition, the Decree of the Directors and Indonesia Bank Regulation (PBI), also support operational regulations in both commercial and sharia banks. Another supporting foundation is the role of the Sharia Supervisory Board (DSN) in providing advice and decisions relating to decision making. The regulations in the implementation of Islamic banking operations based on the DSN-MUI decision are set in PBI in accordance with the Decree of the Directors of Indonesia Bank.

14 Munir Fuadi, Hukum Perbankan Modern Berdasarkan Undang-Undang Tahun 1998 (Bandung: Citra Aditya Bakti, 1999).

15 Mohamed Aslam Haneef et al., INTEGRATION OF WAQF AND ISLAMIC MICROFINANCE FOR POVERTY REDUCTION : Case Studies of Malaysia, Indonesia, and Bangladesh, ed. Savas ALpay and Mohamed Aslam Haneef (The Statistical, Economic and Sosial Research and Training Centre for Islamic Countries (SESRIC), 2015). 
The main law of sharia enforcement that comes from the word of Allah SWT as written in the Quran are as follows as-sunnah (words, actions, and approval of the Prophet SAW), and the results of the thought of fuqaha (the fiqh muamalah expert) which are actualized through 'ijma (deliberation). In accordance with the positive law, mudharabah financing is regulated in article 1 number 25 of Law Number 21 the Year 2008, and DSN Decree Number 07 / DSN-MUI / IV / 2000 concerning Mudharabah Financing (qirad). Similarly, the Bank of Indonesia issues regulations to obtain operational guidelines for mudharabah financing investment products as regulated in article 1 number 3 of Bank Indonesia Regulation Number 9/19 / PBI / 2007.

\section{Results and Discussion}

\subsection{Implementation of Mudharabah Financing Investment Sharing Agreement}

\subsubsection{The Reality of Investment Profit Sharing Concept for Mudharabah Financing}

In general, a sharia bank is a means of intermediation aimed at providing financial services with the sharia principles used in buying, selling, sharing, or leasing. However, it is explicitly the concept of profit-sharing that represents the concept of Islam in banking. Besides being able to move the real sector in a balanced and long-term manner, it contributes to sustainable economic growth. Based on this understanding, ideally, sharia banks utilize the profit-sharing principles of profit and loss in developing their products. ${ }^{16}$

The Micro, Small, and Medium Enterprises Unit (MSME) is the largest economic actor in Indonesia's economic activities because the country is still dominated by sectors with low productivity, such as agriculture, trade, and home industries. This low productivity sector is the focus of MSMEs. This is in contrast to large business units that are more focused on the management industry with large capital. MSMEs become the contra-side of large business units able to survive with limited funds. This, therefore, makes it easier for SMEs to open new businesses and absorb more workers in a relatively fast time.

This research was conducted at several sharia banks in Jakarta, namely Bank Muamalat Indonesia, Bank Syariah Mandiri, BRI Syariah, BNI Syariah, and Mega Syariah Bank, with the principle of profit-sharing investment mudharabah financing. To date, the product is not superior to sharia banking. The operational principle of profit-sharing in sharia banking is expected to contribute to the economy and as a basis for the growth of the real sector by empowering MSMEs. However, there are lots of obstacles associated with this system due to the

16 Nur Gilang Giannini, "Faktor Yang Mempengaruhi Pembiayaan Mudharabah Pada Bank Umum Syariah Di Indonesia," Accounting Analysis Journal 2, no. 1 (2013): 1-4. 
non-interest or profit-sharing policy associated with Sharia banking. Conventional bank interest is an avoidance for MSMEs as business loan capital, consequently, it is stagnant ("Journal of Islamic Law and Economics," 2006). Profit-sharing financing is a special attraction for SMEs in developing their business because it fosters UMKM expectations in sharia banking with the existence of mudharabah profit-sharing financing as one of the superior products. ${ }^{17}$

Islamic banks do not have the capabilities to maximally support the progress of the real sector, especially MSMEs. This is because the financing products provided by Sharia banking in Indonesia are dominated by non-profit sharing, such as murabahah and ijarah (leasing). The concept of financing with the principle of profit-sharing is associated with sharia financing and a means of moving in the real sector, to improve direct relations, with risks shared.

\subsubsection{Priority Scale for Sharia Products}

The contribution of Islamic banking is determined by its ability to distribute funds to the public. This capability is considered to increase the maximum production of the community, because Sharia bank uses a mechanism for profit sharing, such as the mudharabah agreement. In reality, the profit-sharing agreement mechanism does not show a high overall percentage of the activities in Sharia banking, especially in mudharabah financing investments. ${ }^{18}$

In 2010, the sharia banking statistics released by Bank of Indonesia, presented the results of an analysis of total mudharabah investment financing of Sharia Commercial Banks (BUS) and Sharia Business Units (UUS) rising rapidly above 65\%, from 5,958 T to 9,837 $\mathrm{T}$ in 2009 . Factually, financing with mudharabah, istishna (order), and ijarah agreements dominates approximately $60 \%$, while mudharabah and musyarakah is known as products with profitsharing concepts only account for $35 \%$ of all fund distribution products.

The data presented and the phenomenon of the decline in financing to deposit ratio (FDR) shows that BUS and UUS prefer being "safe-players" to "risk-takers." This is because non-profit financing is a "safe" instrument in terms of channeling funds. Similarly, the buying, selling, and leasing agreements are "safe," because the Sharia bank is certain to acquire profit margins from the implemented agreements and almost no risk of loss, except the threat of non-payment installments from customers.

17 Muhammad Busthomi Emha, “Analisis Pengaruh Pembiayaan Mudharabah, Musyarakah, Dan Ijarah Terhadap Kemampu Labaan Bank Muamalat Di Indonesia,” 2014.

18 Novi Fadhila, "Analisis Pembiayaan Mudharabah Dan Murabahah Terhadap Laba Bank Syariah Mandiri," Jurnal Riset Akuntansi Dan Bisnis 15, no. 1 (2015): 65-77, https://doi.org/10.30596/jrab.v15i1.427. 
Mudharabah is an agreement in Sharia banking based on a business partnership with the principle of profit-lost-sharing (PLS), which has a high risk that causes banks to face difficulties in making it a mainstay product. This profit-sharing principle requires banks to take financial risks because assuming the business they fund does not produce a profit, the Sharia bank also bears the loss.

In reality, the most dominant sharia banking product today is Murabaha products with the principle of buying and selling due to the low-risk margins. This situation clearly explains that Islamic banks are averse to risk, therefore, they need to prioritize products with the concept of profit-sharing as mandated by the law is still difficult to apply.

\subsubsection{Identification of Growth and Composition of Mudharabah Investment}

Sharia banking statistical data for February 2010, showed that Third Party Funds (DPK) generated by BUS and UUS amounted to 53,299 T. This amount increased more than $40 \%$ compared to March 2009 at 38,040 T. This increase in deposits was not accompanied by the composition of financing as seen in FDR. In March 2009, the composition of financing amounted to 39,308 T with FDR 103.33\%, and in February 2010, it increased to 48,479 T with $90.96 \%$ FDR.

This phenomenon is inversely proportional when viewed from the Sharia banking perspective. One of the main differences between Sharia and conventional banks based on interest (usury) in financing is the principle of profit sharing. The element of injustice to one party, as conducted on interest-based funding, is eliminated by applying a profit-sharing system that is in accordance with sharia principles. This is also supported by the availability of legal instruments that explicitly regulate Sharia banks. Conversely, the inequality position between debtors and creditors in conventional banks are dismissed, because both parties have equal rights according to the law in mudharabah and musyarakah agreements.

The Sharia bank business scope is very broad and varied, ranging from profit-sharing, sale, lease, fee, to voluntary-based. Sharia banks are no different than an entrepreneur that dares to take risks in conducting business (risk-takers), therefore, it needs to be applied in this way. In fact, presently, the courage is inadequate when seen from the phenomenon of low FDR and the tendency to take "safe" financing products/schemes as stated above, this is an uncertain human resource (SDI) of Sharia banking in carrying out its actual roles and functions. In addition, it is 
understandable because most of the SDI of Islamic banking currently comes from conventional banking, therefore, the inheritance of the conventional mindset cannot simply disappear.

\subsection{Procedure and Stages of Mudharabah Contract Financing and Legal Acceleration}

\subsubsection{Procedure and Stages of Mudharabah Contract Financing}

The procedure and stages of mudharabah contract financing are simply described as follows: 1) Submission of prospective customer proposals, 2) interviews are conducted on prospective customers regarding the type of business they run, the amount of capital needed, and the average profit per day, week, month and year. Large financing schemes are divided into two parts, namely 1) Productive Financing, which is provided for business needs, 2) Consumer Financing, which is provided for the purchase or procurement of certain goods not used for business purposes.

There is a difference in treatment between productive and consumptive financing in accordance with the analysis approach utilized. In consumptive financing, analysis is carried out to determine the personal financial ability received. Meanwhile, on productive financing, the focus of the analysis is directed at the capability of the business to pay off the loan received. In terms of the process, the analysis of productive financing is more complicated than consumer financing.

\subsubsection{Legal Acceleration of Mudharabah Financing}

Before the sharia banking law was passed, it functioned appropriately in Indonesia. However, although the constitution currently supports it, it is not regulated in the legislation. In addition, due to the enactment of Law Number 7 of 1992 concerning banking, which amended by Law Number 10 of 1998, the provisions on Islamic banking are very minimal. Therefore, it is not an answer to the uniqueness and specificity of the financial institution.

In line with the enactment of Law Number 7 of 1991, the Government Regulations (PP) No. 72 of 1992 concerning Banks was based on the profit-sharing principle. Furthermore, Law No. 10 of 1998 is stated more decisively, with its weaknesses in the perspective of Sharia banking is the applicable rules and regulations aimed at all banks. Indonesian Bank Regulation (PBI) supervises and oversees all banking operations in Indonesia. The PBI created after November 1, 2004, are considered to have legal force, while those created after this date need to be adjusted in accordance with Law No. 10 of 2004. This is because PBI is not included in the 
national legal hierarchy. Therefore, its emergence needs to be in line with the laws and regulations mentioned in Article 7, including the Constitution, Perpu, Law, PP, and Perpres (Article 7 paragraph 4 of Law No. 10 of 2004).

The law on sharia banking regulates the types of businesses, implements strategies, business feasibility, distribution of funds, and prohibits BUS and UUS, which are part of conventional commercial banks. The law that regulates explicitly sharia banking also controls the compliance whose authority lies with the Indonesian Ulema Council (MUI) and National Sharia Board (DSN), represented through the DPA formed on each BUS and UUS. The Ministry of Religion creates elements in the society with a balanced composition to follow up the implementation. One source of legal references regarding Sharia Banking is the MUI decision, which is usually prepared and issued by the MUI National Sharia Board (DSN MUI).

The decision has a basis with the existence of Law No. 21 of 2008 concerning Sharia Banking, which is used to determine the details of the Sharia principles being registered by MUI, at Committee formed by Bank of Indonesia. Based on these provisions, the MUI decision becomes a positive law that is recognized in the Indonesian constitutional system.

Currently, there are a total of 11 Sharia Commercial Banks (BUS), 23 Sharia Business Units (UUS), and 146 Sharia People Financing Banks (BPRS) with a network of 1,625 offices, according to data obtained at the end of September 2010. Geographically, the distribution of office networks is across more than 89 districts/cities in 33 provinces. The results of this research showed that Sharia banks have not optimally conducted fund distribution activities with the principle of profit-sharing through mudharabah products on MSMEs. Data obtained from the six (6) Islamic banks studied, stated that the operation of the temporary mudharabah product was only limited to groups or organizations. However, all Sharia banks have not been able to implement it on individuals because the MSMEs have not been able to fulfill the various requirements.

\subsection{Factor Affecting Mudharabah Profit Sharing Covenants}

\subsubsection{Factors that Differentiate Profit Sharing From Interest}

Direct factors, is the factors affecting the calculation of profit-sharing are as follows: 1) Interest rate, which is the total percentage of funds invested. An interest rate of $80 \%$, means that $20 \%$ is allocated to fulfill its liquidity, 2) Mudharib, 3) the amount of funds available from various sources of investment, calculated using the average monthly minimum balance method, 
and 4) Profit sharing ratio. One of the characteristics of mudharabah is that the profit-sharing needs to be determined and agreed at the beginning of the agreement. It differs between banks and changes with time.

Indirect factors, these are factors used to determine the income and costs shared by banks and customers in terms of revenue and expenses. The term revenue refers to the income received with less operating costs, while profit and sharing are appropriately used between Shahibul Maal and Mudharib with advantages and disadvantages. Another type of indirect factor is the accounting policy, which consists of principles and methods. Profit-sharing is indirectly affected by the activities implemented, especially relating to revenue and cost disclosure.

\subsubsection{Limitations and Advantages of Mudharabah Investment Profit Sharing Agreement}

Sharia banking in Indonesia still favors non-profit-sharing products, such as buying and selling(Murabaha) as well as the distribution of funds due to the following: 1) non-sharing murabahah and ijarah financing consists of fixed return modes, where the characters that principally distinguishes between sharia and conventional banks lies in profit and loss sharing, 2) Murabaha schemes encourage increase in the prices of goods and commodities, and 3) Murabaha schemes do not have a significant effect on increasing the productivity of goods and services. In addition, non-profit sharing financing causes problems for the business world and led to low revenue acquisition of sharia banks.

The advantages of mudharabah investment financing with the profit-sharing concepts are as follows: 1) it drives the real sector because this financing is productive and distributed for investment as well as working capital needs,2) The customer is faced with two choices, either to deposit the funds in Sharia banks or conventional by comparing the expected rate of return offered by both, 3) Increase percentage of profit sharing financing which tends to encourage the growth of entrepreneurs or investors that dare to make risky business decisions, 4) its patterns

are productive-based that provides added value to the economy and the real sector, thereby, reducing the possibility of financial crisis.

\subsubsection{Law and Policy}

The House of Representatives (DPR) passed the Law on Micro, Small, and Medium Enterprises (MSME) on June 10, 2008, and on July 4, 2008, the President passed it into Law No. 
20 of 2008 on MSME. This law became an opportunity for Sharia Banking to be fully involved in empowering MSME to create a unified economy based on community empowerment.

According to this law, the objectives of MSME empowerment are as follows: 1) to realize a balanced, developed and equitable national economic structure, 2) grow and develop the ability of MSME into a strong and independent business, 3) increase the role in regional areas, 4) job creation, 5) income distribution, 6) economic growth, and 7) alleviate people from poverty (Article 5 of Law No. 20 the Year 2008). Meanwhile, Law No. 21 of 2008 on Sharia Banking stated that the purpose is to support the implementation of national development in order to improve justice, togetherness, and equitable distribution of people's welfare (Article 3 of the Sharia Banking Law). Based on the equality of both objectives, Islamic banking needs to strive to be a pioneer in the progress of MSMEs based on mutually beneficial and complementary cooperation. In addition, MSMEs need to be prioritized by the government, both in Indonesia and in other countries.

Sharia banking adheres to the principle of profit and risk-sharing, which is suitable for the needs of MSMEs. The law, leads to increased expectations in concrete steps, with the successful implementation of MSME in BRI villages.

According to Karim Business Consulting, sharia financing is still higher than the cost of credit in conventional banks, with a comparison percentage ratio of $18 \%$ and $15 \%$. Sharia banking with $18 \%$ consists of $9 \%$ funds, $2 \%$ profit margin, and $6-8 \%$ operational costs, while conventional banking credit costs are $15 \%$, with $9 \%$ funds, $2 \%$ profit margin, and $4 \%$ operational costs. Therefore, the leading cause of the high cost of sharia banking financing is due to the increase in operational costs than conventional banks.

\subsubsection{Analysis of Criminal Provisions According to Positive Law}

Eradication and prevention of criminal acts of sharia banking need to be carried out professionally by referring to and applying existing laws and regulations, including elements against the law contained in the Criminal Code (KUHP). Sharia Banking refers to criminal acts regulated in the Law, which imposes sanctions on the commissioners, directors, employees, and parties involved in illegal activities.

With regard to criminal acts in the field of Islamic banking, crimes committed internally need special attention. "This type of crime is usually in the form of fraud and self-dealing, which tends to liquefy the majority of bank assets. It is closely related to the dominance of policies and 
administration by a person or group of people and inadequate supervision of internal and external regulators. In addition, various applicable regulations cause banks to take often excessive risks, which leads to lower levels of internal supervision, thereby, leading to higher internal fraud rates. According to sharia principles, derivative transactions do not possess $m a{ }^{\prime} k u d$ 'alaih, in the form of goods and services used in business, therefore, it contains elements of usury, maisyir, and gharar. The monetary and real sectors are inseparable, while in the capitalist system, both are diametrically separated which leads to the rapid flow of money, with decrease in goods, thereby, making both unbalanced. The business activity that separates the monetary and real sectors, as practiced by the capitalist economic system, is the practice of usury, which is also known as derivative according to contemporary terminology. Usury is contributed through derivative and speculative transactions to financial institutions. The criminal law side views the speculative act of derivative transactions as a banking crime.

In addition, existing provisions need to be monitored by all affiliated parties to avoid criminal law snares, which contain elements of negligence, fraud, manipulation, and speculation that is against the law, in the form of prison sanctions and financial fines. Therefore, the violations of all articles are criminal acts, and the parties involved possess high integrity and always train their competence.

\section{Conclusions}

There are lots of problems associated with the implementation of mudharabah financing investment contracts in the real sector through the empowerment of MSMEs such as interest collision, in the Sharia banking activities. Therefore, it has not been maximized in fulfilling expectations as the essence of Law No. 21 of 2008 on Sharia Banking. The following are some of the factors responsible for the improper utilization of mudharabah financing investment agreement: 1) its operations have not been optimally conducted, 2) risk-averse attitude, 3) infant industry with insufficient human resources, and 4) lengthy submission process.

The implementation of mudharabah agreement financing and legal law acceleration on financing investments has a positive impact on the development of the real sector. This is useful as a means of family and social-economic development for MSMEs specifically as an indicator of the economy through investment based on laws and regulations, assuming all parties involved understand and implement sharia principles optimally. 


\section{Acknowledgement}

Acknowledgement to individuals and entities that have provided essential support such as research grants and fellowships and other sources of funding is in a separate page at the end of article.

\section{References}

Abdoerraoef. Al-Quran Dan Ilmu Hukum. Jakarta: Bulan Bintang, 1970.

Alaro, AbdulRazzaq Abdul-Majeed, and Abdulrahman Habeeb Alalubosa. "Potential of Shar 1’ah Compliant Microfinance in Alleviating Poverty in Nigeria A Lesson from Bangladesh." International Journal of Islamic and Middle Esstern Finance and Management, 2018. https://doi.org/10.1108/IMEFM-01-2017-0021.

Ali, Zainuddin. Hukum Perbankan Syariah. 2nd ed. Jakarta: Sinar Grafindo, 2010.

- Hukum Perbankan Syariah. 2nd ed. Sinar Grafindo, 2010.

Amalia, Hanik. "Peran Pembiayaan Mudharabah Pada Baitul Maal Wat Tamwil (BMT) Dalam Melakukan Pengembangan Usaha Mikro Kecil Dan Menengah (UMKM),” 2019.

Dewi, Gemala. Aspek-Aspek Hukum Perbankan Dan Perasuransian Syariah Di Indonesia. Jakarta: Kencana Prenada Media Group, 2006.

Emha, Muhammad Busthomi. "Analisis Pengaruh Pembiayaan Mudharabah, Musyarakah, Dan Ijarah Terhadap Kemampu Labaan Bank Muamalat Di Indonesia,” 2014.

Fadhila, Novi. "Analisis Pembiayaan Mudharabah Dan Murabahah Terhadap Laba Bank Syariah Mandiri." Jurnal Riset Akuntansi Dan Bisnis 15, no. 1 (2015): 65-77. https://doi.org/10.30596/jrab.v15i1.427.

Fuadi, Munir. Hukum Perbankan Modern Berdasarkan Undang-Undang Tahun 1998. Bandung: Citra Aditya Bakti, 1999.

Gatot, Supramono. Perikatan Dan Masalah. Jakarta: Djembatan, 1966.

Giannini, Nur Gilang. "Faktor Yang Mempengaruhi Pembiayaan Mudharabah Pada Bank Umum Syariah Di Indonesia.” Accounting Analysis Journal 2, no. 1 (2013): 1-4.

Haneef, Mohamed Aslam, Ataul Huq Pramanik, Mustafa Omar Mohammed, Mohamed Aslam Haneef, Fouad M Amin, Aliyu Dahiru Muhammad, and Nabil Dabour. INTEGRATION OF WAQF AND ISLAMIC MICROFINANCE FOR POVERTY REDUCTION : Case Studies of Malaysia, Indonesia, and Bangladesh. Edited by Savas ALpay and Mohamed Aslam Haneef. The Statistical, Economic and Sosial Research and Training Centre for Islamic 
Countries (SESRIC), 2015.

Harahap, Syafri. "The Disclosure of Islamic Values - Annual Report The Analysis of Bank Muamalat Indonesia , s Annual Report” 29 (2003): 70-89. https://doi.org/10.1108/03074350310768355.

Hasan, Zubairi. Undang-Undang Perbankan Syariah, Titik Temu Hukum Islam Dan Hukum Nasional, . Jakarta: Rajawali Pers, 2009.

Karim, Adiwarman A. Bank Islam-Analisis Fiqih Dan Keuangan. 3rd ed. Jakarta: Raja Grafindo Persada, 2007.

Muneeza, Aishath, Nik Nurul Atiqah Nik Yusuf, and Rusni Hassan. "The Possibility of Application of Salam in Malaysian Islamic Banking System,” 2011. https://doi.org/10.1108/08288661111135135.

Rahman, Abdul Rahim Abdul. "Islamic Microfinance: A Missing Component in Islamic Banking” 2 (2007): 38-53.

Wardani, Bertha Kusuma, and Joko Pramono. "Perbankan Syariah: Alternatif Pendanaan Usaha Mikro, Kecil, Menengah (UMKM)" 9, no. 17 (2016): 60-78. 